\section{FIRST YELLOW RAIL RECORD FOR REGINA}

by Margaret Belcher, Regina

The Yellow Rail (Coturniccps noveboracensis) recovered by Fred W. Lahrman at the TV tower at Regina on October 7, 1962, and reported in the preceding article of this issue of the Blue Jay, constitutes the first record for Regina.

The bird collected at the tower was shown to me later at the Saskatchewan Museum of Natural History by Fred Lahrman-the first Yellow Rail that I have ever seen. However, I had the good fortune this past summer to hear a Yellow Rail with Manley Callin and a small group of birders who were exploring the marshy meadows at the west end of Pasqua Lake in the Qu'Appelle Valley as part of the field trip program of the Saskatchewan Natural History Society's annual summer meeting (June 16, 1962). The notes we heard were not the commonly described series of "ticking" sounds, but another sequence that Manley Callin recognized as being identical with that recorded by Roger Tory Peterson in his "Field Guide to Bird Songs". Returning from the marsh, we stopped at the Callins' home to listen to the Peterson record and thus verify the identification. Mr. Callin was pleased to find the Yellow Rail at Pasqua Lake since he has heard them farther east in the Qu'Appelle Valley in the marshes at El Capo, Round and Echo Lakes.

This shy and elusive bird is difficult to locate, except by sound, as was well shown by R. D. Symons in his "Random notes on the Yellow Rail" in the Blue Jay, 14:8-19, March, 1956. Locating the Yellow Rail mostly by ear, Mr. Symons was able to plot its range at Moosomin and Davidson, and from Saskatoon through Battleford to Lloydminster and north to Midnight Lake. Records of its being heard in the Carlton area and seen at Prince Albert (C. S. Houston and M. G. Street, Birds of the Sask. River, 1959) and specimens from the north end of Last Mountain Lake (Carnegie Museum, Pittsburg), Battleford and Somme (SMNH), help to confirm the impression that the distribution of the Yellow Rail is rather general throughout Saskatchewan in suitable habitat.
Dr. R. W. Nero has called attention to the fact that Yellow Rails do not appear to have been commonly reported at TV tower kills. In the survey of casualties at a Florida tower (Herbert L. Stoddard. 1962. Bird casualities at a Leon County, Florida TV tower, 1955-1961) not a single Yellow Rail was found, although it is considered a much commoner bird than the little Black Rail of which three specimens were collected. Again, when the results of five tower-kills in Wisconsin from 1957 to 1959 were tabulated (Charles A. Kemper. 1959. Mcre TV tower destruction. Passenger Pigeon, 21:135-142) two immature Yellow Rails were considered among the most remarkable specimens.

\section{A GOLDEN-WINGED WARBLER IN REGINA}

by Frank Brazier, Regina

At 8:30 a.m. on May 18, 1962, I was walking in the Legislative Grounds in Regina when I noticed a number of small birds on a lawn. As I raised my binoculars a small grayish and yellow bird, superficially like a Myrtle Warbler, flew across my path and into a nearby tree. Myrtles were plentiful and I paid no particular attention to this bird. While I inspected those on the lawn (they were Chipping Sparrows), however, something about this one nagged at me, and suddenly I got it-no yellow rump! I swung my $10 \times 50$ 's to where the bird obligingly waited, back towards me. I stared in disbelief . . . no rump patch, and dull yellow shoulders-I suspected the unbelievable . . and then it turned and faced me-an adult male Golden-winged Warbler (Vermivora chrysoptera)! In bright sunlight his golden forehead, black face bar and black throat at no more than 30 feet were unmistakeable. And then he sang-his unpretentious vocal effort turned out to be the second song described in Griscom and Sprunt's The Warbler.s of America (New York, Devin-Adair, 1957).

Griscom and Sprunt give the breeding range as from southeast Manitoba, central Minnesota, southeast Ontario, central New York and southern Vermont, and Massachusetts south to southern Iowa, northern 